This item was submitted to Loughborough's Research Repository by the author.

Items in Figshare are protected by copyright, with all rights reserved, unless otherwise indicated.

\title{
On territory, the nation-state and the crisis of the hyphen
}

PLEASE CITE THE PUBLISHED VERSION

http://dx.doi.org/10.1177/0309132508104996

PUBLISHER

Sage $($ ) the author

VERSION

AM (Accepted Manuscript)

LICENCE

CC BY-NC-ND 4.0

REPOSITORY RECORD

Antonsich, Marco. 2019. "On Territory, the Nation-state and the Crisis of the Hyphen". figshare. https://hdl.handle.net/2134/12994. 
This item was submitted to Loughborough's Institutional Repository (https://dspace.lboro.ac.uk/) by the author and is made available under the following Creative Commons Licence conditions.

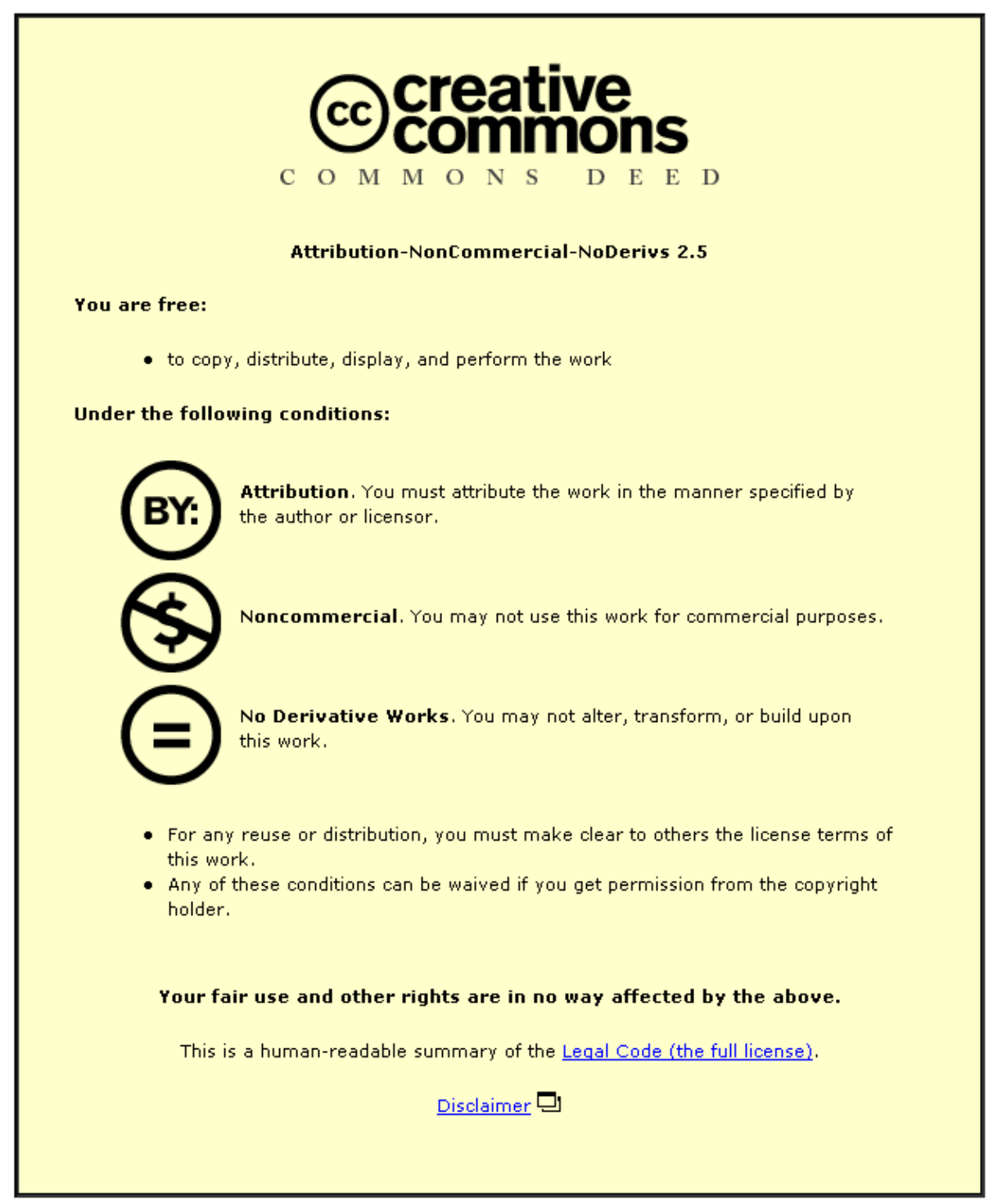

For the full text of this licence, please go to: http://creativecommons.org/licenses/by-nc-nd/2.5/ 


\title{
On territory, the nation-state and the crisis of the hyphen
}

\begin{abstract}
This article aims to stimulate a new theoretical debate around the notion of territory in the age of globalization. Rather than espousing the neoliberalist view on de-territorialization or contributing to the examination of the new 'spatial fixes' associated with the re-territorialization of modes of capital production and accumulation, the article focuses on the politicoinstitutional dimension of territory. My argument is that we should not limit our understanding of territory to a device in the hands of the state to control and to contain people, but explore the role that territory plays as a principle of social organization and integration in today's multicultural societies. This argument is discussed in relation to the so-called 'crisis of the hyphen', i.e. the increasingly problematic link between the nation and the state within Western European societies.
\end{abstract}

\section{Introduction}

In the early 1990s, a new era of 'end-ism' emerged as a sort of Western dominant discourse. Following the famous 'end of history' by Fukuyama (1989), new titles were published, both within and outside academia, announcing the 'end of geography' (O' Brien, 1992), the 'end of the nation-state' (Guéhenno, 1995; Ohmae, 1995), and the 'end of territory' (Badie, 1995). The general idea behind this end-ism was that the triumph of Western democracy and its market economy would have brought a new era of cultural and geographical homogeneity, a borderless world or, to use a more recent image, a 'flat world' (Friedman, 2005).

Since then, geographers and other scholars have shown the flaws of this end-ism, pointing instead to the explosion (i.e. the proliferation) of 'geographies' and, echoing Deleuze and Guattari (1987), to the idea that any de-territorialization is also a form of re-territorialization (Ó Tuathail and Luke, 1994; Sassen, 1996; Cox, 1997; Graham, 1998; Yeung, 1998; Sparke, 2006). In other words, in the age of globalization place still matters - as demonstrated, among others, by economic geographers (Scott and Storper, 2003); borders also still matter, as a growing literature, prompted by the above mentioned borderless claim, has largely shown (for a review of this literature see Newman, 2006). What seems missing, though, in this reassertion of the importance of the 'geo' in our present societies, is an attention to the space which is bounded, i.e. territory. Of course, territories still matter, as the lives of the majority of individuals are still today attached to a bounded politico-institutional space. Yet, it is clear that territory has not received the same attention as the concepts of place and borders. Why? I believe that its close link with the state might account as the major reason. Traditionally associated with the modern state first and the nation-state later (Teschke, 2002), territory has indeed been perceived mainly as a device to control (Sack, 1986) and to contain (Taylor, 1994) people - i.e., territory as an oppressive tool in the hands of the state. Not surprisingly, critical geographers, at least from the 1980s, have increasingly turned their back to notions of bounded space, privileging (and celebrating) instead a notion of progressive and social empowering place (Massey and Jess, 1995). Those (political) geographers who have continued to focus their attention on territory have done so from a rather traditional perspective, treating 
territory as the stake in conflictual situations and/or as a source of (national or ethnic) identity (see, among others, Knight, 1999; Murphy, 2002; Yiftachel, 2002; Herb, 2004; O' Loughlin and Ó Tuathail, forthcoming).

As the nation-state is experiencing today a profound transformation, not only in relation to the re-scaling of governance and modes of economic production at the suband supra-national levels (Brenner et al., 2003), but also with regard to the ethnic composition of its populace, I argue that territory deserves to be further investigated in its role of binding people together beyond the nationalist idea(1) of one territory, one 'people' (in cultural/ethnic terms). Notwistanding the persistence of both this idea(l) and the scholarly argument that territory is inherently oppressive and somehow 'out-of-place' in an era of networks, flows and global mobility, I argue that, in the present post-national, multicultural, and transnational epoch, the need to study how territory implicates and is implicated in discourses and practices of social integration, belonging, and loyalty beyond the spatial congruence between nation and state is most topical. ${ }^{1}$

The paper is divided into five sections. Following this introduction, in the second section I discuss the changing ethnic composition of Western European societies which, among other factors, reveal what, after Appadurai (1990), I call 'the crisis of the hyphen', i.e. the increasingly problematic convergence between nation and state. Two related sub-sections deal here with the ways in which Western European governments have essayed to tackle this crisis and the ways in which scholars have essayed to go beyond the hyphen by envisioning post-national scenarios. In the third section, I examine the meanings of territory as discussed in the geographical literature, showing the 'negative' connotation that characterizes territory as a normative principle and its marginality within analytical views on globalization. In the fourth section, I explore the relevance of territory as a principle of societal integration beyond national claims of ethnic or cultural sameness and interrogate the ways in which this can be studied. Finally, as a way to conclude, I engage further this hypothesis, by engaging additional questions related to the notion of territory as a post-national principle of societal integration. For an illustrative purpose only, the paper focuses on the case of Western Europe.

\section{Nation-state: the crisis of the hyphen}

A quick look at OECD demographic data for Western European countries reveals that every year international migration contributes more and more to population growth compared to natural increase (OECD, 2007). In economic terms, this means that the future well-being of Western Europeans will be increasingly dependent on stocks of foreign immigrants, as without positive net migration, the working-age population of the countries of Western Europe at some stage will start to decline and so will its national welfare (OECD, 2007: 30). The social consequence of this economic trend is that Western European societies are deemed to become more and more multi-cultural. At the moment, this social transformation is somehow distorted by restrictive immigration policies adopted by many Western European countries. Yet, the figures about the stocks of foreign population living in Western Europe are already significant. In 2005, the datum about foreign-born individuals as a percentage of the total population was equal to $8.3 \%$ in Western Europe. ${ }^{2}$ Italy (2.5\% - datum 2001) and Finland (3.4\%) were the countries with the lowest values, whereas Austria 
(13.5\%) scored at the top, followed by Germany (12.9\% - datum 2003), Sweden $(12.4 \%)$ and Belgium (12.1\%). It is important to note that these figures capture only partially the changing ethnic composition of Western European societies, as they do not take into account undocumented aliens and 'second generation immigrants' these latter defined as native-born children of foreign-born parents (OECD, 2007: 77). In Germany, for instance, in 2005 there were about 15 million individuals with an immigration background, nearly $20 \%$ of the total population - even though many of them can be counted as ethnic German returnees (Population and Development Review, 2006). By 2010, it is expected that $50 \%$ percent of the population under the age of 40 living in Germany's large cities will have an immigrant background (Ibid.). According to a United Nations demographic projection, by 2050 about $60 \%$ of the total populations of Germany, France, and Italy will be descendants of foreign-born persons (United Nations, 2000 quoted in Berezin, 2003: 27).

These figures on the changing ethno-demographic composition of Western European societies offer only a partial evidence of the crisis of the hyphen. Obviously, a more in depth understanding should take into consideration emigration flows and explore the social dynamics imbricated in immigration, ethnicity and culture, beyond a mere statistical account. Moreover, the changing ethnodemographics per se is only one side of the erosion of the spatial congruence between nation and state, as this should also be explained in relation to other economic (e.g. global financial flows), political (e.g. devolution of powers to sub- and supra-national institutions), and social (e.g. increasing apathy of voters or tensions between secular and religious allegiances) factors (see, for instance, Bobbitt, 2003). Yet, the figures presented above constitute a relevant entry point into the exploration of a phenomenon widely felt across the globe. In fact, even though, for explanatory reasons, in this paper I focus only on the case of Western Europe, it is important to note that the crisis of the hyphen is by no means confined only within this part of the world, as it affects, to different degrees, also other regions of the world (Appadurai, 1996).

To be sure, what I call the spatial convergence between state and nation should be taken with caution. Throughout history, this convergence has always been problematic, as the nationalization of masses has constantly encountered various obstacles, including the persistence of people's linguistic and cultural differences. What I mean by the above convergence, therefore, is more a discursive than an actual dimension. In their rhetoric, national political elites have indeed constantly resorted to this discourse as a way to legitimize the existence of the nation-state. However fictitious it can be, the spatial convergence between the nation and the state has therefore been a powerful, hegemonic discourse. Yet, in the present era of 'timespace compression', scholars from different disciplines have started challenging more acutely this discourse. Following the reasoning of Tully (1995), the sociologist Nikolas Rose, for instance, has suggested that "it is no longer easy for political thought to territorialize itself in an apparently 'natural' geo-political space in which the nation is coextensive with and delimited by a unified polity of social citizens" (Rose, 1996: 352). Cultural anthropologists have pointed into the same direction (Gupta and Ferguson, 1992; Appadurai, 1996a). According to Appadurai, for instance, the isomorphism between people, territory and sovereignty which the nation-state has attempted to consolidate throughout its history is today under threat mainly from the circulation of people (Appadurai, 1996: 43). This means that "territory as the ground of loyalty and national affect [...] is increasingly divorced from territory as the site of sovereignty and state control of civil society" (Ibid.: 47). 
Political geographers have confirmed this point (Paasi, 2003: 470) and have browsed new spatial settings beyond the nation-state, by privileging both an economicfunctional perspective (Taylor, 1995, 2000) and a genealogical analysis of the institutional forms of territory (Agnew, 1994, 1999; Lévy, 2007).

Clearly, international mobility of people, among other factors, poses today a serious challenge for the nation-state, as in the present epoch being a member of the state does no longer imply being a member of the nation. The periodical riots in the French banlieues are just one of the many examples which testify of this decoupling (Roy, 2005; Cesari, 2005).

\section{Tackling the crisis of the hyphen: governments' responses}

As a way to tackle the crisis of the hyphen, governments in Western Europe have resorted to two opposite strategies. On the one hand, they have essayed to 'deethnicize' the nation, by re-writing its identity in civic terms. On the other hand, they have adopted stricter immigration and asylum laws, introduced citizenship tests which check for the compatibility of the culture of the new comer with the dominant culture of the receiving country, and discussed the possibility of expulsion of foreign residents who commit a crime - all measures which, I would argue, indirectly aim at preserving the ideal of a cultural-ethnic character of the nation and defuse de facto the first strategy. ${ }^{3}$

The phenomenon of the 'de-ethnicization' of the nation is particularly evident in Britain, where Gordon Brown, former Chancellor of the Exchequer and actual Prime Minister, has attempted, in the last five years or so, to revive a sense of Britishness, perceived to be under threat both from secessionism (mainly in Scotland) and multiculturalism (Lee, 2006). In his search of the 'ties that bind us together', Gordon Brown intentionally overcomes a definition of the nation as a cultural-ethnic ensemble and turns instead to a civic vocabulary, made of common values (passion for liberty, sense of duty, commitment to tolerance and fair play), shared interests, and a set of common institutions (the Monarchy, the Parliament, the Armed Forces, but also the National Health System, the BBC, the National Insurance, etc.) (Brown, 2004, 2007). Brown's discourse is certainly not an isolated or occasional one, since various official reports on multiculturalism published in Britain during the last decade have equally put forward a similar strategy (Runnymede Trust, 2000; Home Office, 2001; Commission on Integration\& Cohesion, 2007).

This re-writing of the identity of the nation in civic rather than in cultural-ethnic terms characterizes, even though to a lesser degree, other major European countries. During the 2007 political campaign for the French presidential election, the actual President, Nicholas Sarkozy, reinforced the idea of France as a nation based on the universal principles of human rights. His slogan ('new French dream') was indeed aimed at creating a nation "where diversity is not seen as a threat, but as richness", a nation based on the respect for any human being, 'une République fraternelle' established on the principle of 'full citizenship' (La Tribune, 2007). Also Germany has moved towards a more civic definition of the nation, first with the adoption of the new law on citizenship (2000), which tempers the jus sanguinis (citizenship acquired only via German ancestors) with an element of jus soli (citizenship acquired either by being born or having resided for a certain amount of time in Germany), and, more recently, with the adoption of the National Integration Plan, which officially 
acknowledges that Germany is made up of multiple cultures, primarily bound together by the respect of the Basic Law and German language. ${ }^{4}$

These attempts to re-write the nation as an entity which is not associated with a pre-given 'people', defined in cultural and ethnic terms, have been, however, accompanied by opposite measures, which indirectly confirm what exactly the first strategy aims to overcome. Stricter immigration and asylum laws have been adopted or discussed in many Western European countries. Some of these laws have been accused of discriminating against particular ethnic groups. In Germany, for instance, the major Turkish associations boycotted the meeting which launched the National Integration Plan, as a way to protest against the tightening of Germany's immigration laws approved by the Bundestag just few days before that meeting. The new law requires, among other things, that the spouse of the foreign immigrant has a basic knowledge of German before she can obtain a resident permit. The Turkish associations, supported in their claims by the then Turkish Foreign Minister Abdullah Gül (the actual President of Turkey), argued that this law introduced a serious discrimination among different nationalities, as the language requirement did not apply to spouses of citizens of Australia, Israel, Japan, Canada, South Korea, New Zealand, and the United States. ${ }^{5}$ Similar protests about a double standard (one for natives, the other for immigrants) were also recently heard in France, after the Parliament approved (23 October 2007) the DNA test for prospective immigrants wishing to join family members already living in France.

Accompanying the tightening of immigration policies, some states have also introduced citizenship tests. Traditionally, these tests have been adopted in the past as a way of curtailing and/or selecting immigration flows (Etzioni, 2007). Now, however, they seem to play a different role, as more and more countries use them as a way to guarantee the integration of the future citizen within the dominant culture of the receiving country. In the case of Britain, the Life in the UK test, introduced in 2005, revolves around a set of factual questions which simply aim to familiarize the future citizen with the institutional and practical aspects of British life. In other countries, however, questions have not only been formulated to test the knowledge, but also the opinion of the respondent, so as to evaluate whether the culture of the future citizen matches the dominant culture of the receiving nation. In the case of the German Land Baden-Württemberg, the citizenship test, in force since January 2006, asks any applicant of Muslim religion what he (the test seems indeed to target men rather than women) thinks about women and homosexuality issues (Valentino, 2006). An analogous test introduced in March 2006 in another German Land, Hessen, adopts similar questions, asking, for instance, the Muslim applicant whether he believes in Israel's right to exist and whether a woman should be allowed out in public without the accompaniment of a male relative (Corbett, 2006). Similar tests which check for the degree of cultural adaptation of the future citizen are also held in Switzerland and in the Netherlands - the test in this latter country has been introduced in 2005, after the shock caused by the murder of the film-director Theo Van Gogh by a Dutch citizen of Moroccan descent. In Switzerland, the second Western European country for percentage of foreign-born persons (23.8\%), the Swiss People Party, the largest party in Switzerland and member of the governing coalition, has recently (September 2007) campaigned for a law which would authorize the expulsion of foreign families, in case any family member were to be found guilty of violent crime, drugs offences or benefit fraud (Foulkes, 2007). The campaign, which was preceded by another initiative by the same party aimed at banning the construction of minarets in Switzerland, clearly confirms what we have already seen above: despite the attempts 
of some government to 'de-ethnicize' the nation, its ethno-cultural elements are somehow reproduced by other measures adopted by the same governments or political parties.

\section{Going beyond the hyphen: normative responses}

While governments have dealt with the crisis of the hyphen by adopting measures aimed at re-consolidating the hyphen itself (either by re-writing the meaning of the nation in civic terms and/or by preserving its ethno-cultural dimension from additional migration - particularly from Muslim countries, the one which is perceived to be the most threatening), some scholars have instead questioned the structural link between the nation and the state, envisioning new politico-institutional forms which go beyond the hyphen. This 'post-national' argument finds its most sophisticated theorization in the works of the German philosopher Jürgen Habermas, whose argument relies on the normative distinction between the cultural (the nation) and the political (state). ${ }^{6}$ Simply put, Habermas rejects the dominant discourse associated with the nation-state, which demands the sharing of a common culture or ethnicity as a necessary condition for democracy (Habermas, 2001: 73). For him, what matters are the procedural properties associated with the democratic process. In other words, the process of public opinion- and will-formation is what produces the common political bond, irrespective of the different cultures to which individuals can be attached. In an era of multiculturalism, Habermas contests the idea that the nation as a pre-political community of shared descent and destiny can legitimize the existence of the state. Rather than an ethnos, made up of individuals who share the same 'we' feeling, Habermas speaks of a demos, an ensemble of individuals bound by the same law, i.e. citizens. For him, the key factor on which a democracy relies is not the sharing of a pre-existant collective identity, but a liberal political culture which guarantees that decisions are adopted following a deliberative process based on the rationality of the actors involved (Habermas, 1992: 11; Habermas, 1998: 159). The end result is what Habermas calls 'constitutional patriotism', i.e. a patriotism which is not directed towards the nation which the state supposedly embodies, but to the system of laws created through a consensual and rational process.

Habermas's theory has been criticized under many aspects. The rationality of the process of public opinion- and will-formation has been challenged as an ideal-type rooted in morality (Mouffe, 2005: 13), which also finds little historical evidence (Calhoun, 1992a). Communitarian authors have pointed out that democracy cannot exist without a 'we' feeling, which only a nation conceived in cultural (or ethnic) terms can generate (Miller, 2000). Consequently, the idea of constitutional patriotism has been accused of being too abstract to be able to mobilize people and their sense of belonging (Cederman, 2001). Nevertheless, Habermas's theory has the merit of challenging the reification of the spatial convergence between nation and state and as such it opens up room for thinking about territory beyond a nationalist perspective which focuses on territory merely as the 'embodiment' of the nation. This latter perspective falls indeed short when it comes to explain the role of territory in a context in which, due to the multiplication of national-cultural references held by people, the nation itself becomes a problematic concept. There is therefore a need to investigate the ways in which territory intervenes, both discursively and practically, in shaping present societies in a post-national fashion. Before discussing further this 
point, it is necessary to introduce the notion of territory as so far theorized in social sciences.

\section{Territory and place in the age of globalization}

It is rather surprising that despite being considered as the major defining concept of political geography (Cox, 2002: 1), territory is a notion that various geographers in various epochs have said to be under-theorized. In the 1970s, Gottmann (1975: 30) lamented that both political scientists and geographers were taking territory for granted, as a self-evident attribute of established governmental institutions, rather than investigating its qualities. Almost twenty years later, a political scientist remarked how little his fellow colleagues in the field of international relations had studied the concept of territoriality (Ruggie, 1993: 174). In the early 2000s, it was again the turn of a geographer to lament the lack of major theoretical studies on the notion of territory (Paasi, 2003: 110). As pointed out by Delaney (2005: 9), who has recently dedicated a book to this concept, territory has been generally treated by different disciplines as a simple aspect of something more relevant to be studied, e.g. sovereignty (in international relations), culture (in anthropology), or privacy (in environmental psychology).

The few studies that have essayed to deal theoretically with the notion of territory have done so by exploring either its 'natural', i.e. ethological and biological component (Ardrey, 1967 - see also Soja, 1971), or its anthropological dimension (Sack, 1986; Storey, 2001; Delaney, 2005). While the former perspective indirectly legitimizes the idea of 'one territory, one people', as epitomized in modern times by the nation-state (Grosby, 1995; Penrose, 2002), the latter treats territory or, better, territoriality as a control strategy which can be adopted by groups and individuals in various aspects of social life (Sack, 1986 - see also Taylor, 1988). In both cases, the analysis spans from the micro-scale of the inter-individual space to the macro-scale of global politics. Everything can be a territory.

Although I do not negate the use of territoriality in many aspects of the interindividual and social life, I would like here to focus on the notion of territory as a politico-institutional space. It is in fact this notion that today risks to be marginalized by the occurrence of two concomitant factors. On the one hand, the crisis of the nation-state both as a sovereign container (Ruggie, 1993; Agnew, 1994; Taylor, 1994, 1995; Anderson, 1996) and as an identity container (due to the rise of multiple forms of identity politics - see, for instance, Keith and Pile, 1993; Rose, 1995; Pratt, 1999; Judt and Lacorne, 2004) is at times read as the crisis of the spatial principle on which the nation-state has relied, i.e. territory. On the other hand, in the age of global flows, internationalization of markets, international mobility of people, and multiculturalism, the idea of a flexible, pluri-scalar, 'open' place has somehow gained momentum as the dominant analytical and normative paradigm in human geography (Castree, 2004), pushing territory, the politico-institutional bounded space, to the side (Painter, 2006). Hybridity, ambiguity, blurriness, porosity, etc. have become the new catch-phrases which indirectly contribute to reject as modern, old-fashioned, and traditional any argument which elicits lines of inclusion/exclusion. As maintained by an IR author particularly influent among critical political geographers, the challenge ahead of us is not to study what a line separates, but what is on the line (Walker, 1993). Accordingly, the very geographical 'line', i.e. the physical boundary which 
divides space and people on this space, has been re-written in terms of a 'social' rather than a 'territorial' concept, as more and more geographers, drawing on the contribution of social theory, have turn their attention to the 'bounding' practices and discourses mobilized by forms of identity politics (Newman, 2003, 2006).

These studies have certainly opened new ways of conceptualizing socio-spatial relations in the present epoch. Yet, in the process of going beyond the spatiality of the nation-state, I think that something has been lost. Briefly put, I have the sensation that the baby has been thrown away with the bath water. Territory, rather than being explored under the new conditions of globalization, has simply been discarded with the nation-state itself. In the quest for overcoming the embedded statism of social sciences (Agnew, 1994; Taylor, 1996; Häkli, 2001), territory has been by-passed as a way to go beyond the state and its monopoly over socio-spatial formations.

To be sure, the notion of territory as it is known today certainly originated with the rise of the modern state. As pointed out by Alliès (1980), territory was a legal 'invention' of the jurists of the European monarchical states in the $18^{\text {th }}$ century which allowed the absolute power embodied by the monarch to abolish the heterogeneity of places and make them (and the different peoples who lived within them) equal under the law (i.e. the monarch/state). In this sense, territory was used as a tool in the hands of the state for standardizing, homogenizing and disciplinizing social and material reality - one of the practices of governmentality through which, as shown by Foucault, modern statehood was formed and reproduced (Ó Tuathail, 1996: 7-9 - see also Hannah, 2000; Braun, 2001; Elden, 2007).

This historical function of territory as a disciplinizing device sums up with the ones already seen above - territory as a strategy to control people and to contain society - and explains why critical geographers have preferred to focus their attention on open, relational places rather than on something which is bounded. Territory resounds too closely with the oppressive practices of the state; conceptualized as a fixed container, it fails to grasp the complexity of a society which is becoming more and more hybrid in its identity forms; in an epoch of flows, it stands for an oxymoron. On the contrary, the notion of a 'progressive (sense of) place', which is 'open' to flows and is articulated in topological rather than areal scalar terms (Herod and Wright, 2002; Howitt, 2003), promises to be a better conceptual device for grasping the spatiality of actual societies or for normatively prescribing it (Amin, 2002a). This type of place evokes the complexity and dynamics of social life. Not fixed at any given scale, it is presented as an exemplary conceptual device to look at the relationship between human agency and space (Agnew, 2002: 60) and often celebrated, in opposition to the bounded space of the state, as empowering and liberating societies (Massey and Jess, 1995 - see also Maier, 2007).

What here is at stake is not the opposition between territory and place (two terms which colloquially are indeed used as synonyms), but between a type of space conceived as unbounded, open, and relational and one which clearly remains demarcated by a boundary. In this regard, the point is not only to suggest that there might be nothing, ipso facto, regressive about bounded spaces (Forsberg, 1996; Escobar, 2001; Castree, 2004) - as well as nothing ipso facto progressive about an open, relational place (Oakes, 1997) - but also that by wishing territory away, the reality of societies organized in politico-institutional bounded spaces does not simply disappear. Therefore, the task which awaits geographers is not only, as put by Forsberg (Forsberg, 1996: 357), to theorize or analyze how space is being reterritorialized in the age of globalization. There is no short of studies which investigate the new 'spatial assemblages' or 'spatial fixes' associated with the post- 
Fordist modes of economic production (see, among others, Brenner, 1999; Jessop, 2000; Sassen, 2006). The task, I would argue, is also to investigate the present role of territory both as a unit of political organization and a principle of social integration with regard to the ethnic transformation of national societies. I contend that to bring territory back into the empirical and normative discussions over the crisis of the hyphen can offer an additional perspective to reflect on the question about 'the ties that bind'.

\section{Investigating territory as a principle of societal integration}

The act of boundary-making as a way of social organization is far from disappearing in today's world (Newman, 2006). Even if we do not have to go as far as Williams (2003), claiming that borders have an ethical value per se, as they contribute to the protection of human diversity, it is a matter of fact that people's lives continue to be rooted in politico-institutional bounded spaces. Drawing on the works of Carl Schmitt and his notion of the political as the distinction between amicus (friend) and hostis (foe), Mouffe (1999: 43) maintains that any democratic regime cannot avoid a moment of closure, which is the very act constitutive of the demos or, according to other authors, of democracy itself (Zielonka, 2006: 183). Among geographers, Staeheli (2007: 5) has raised a similar argument, by affirming that, at some moments or in some arenas, exclusion is what allows communities to be built and empowered (see also Mitchell, 2006a: 97).

In general, though, social scientists have been rather wary of any act of enclosure, fearing indeed the exclusion which is generated (cfr. Vasudevan et al., 2008). My opinion is that while we should not forget to investigate this aspect, we should also not neglect to explore who is included and how. What collective practices and discourses, which do not just speak the nationalist language of ethnic or cultural sameness, are generated by the prosaic act of living together within a politicoinstitutional bounded space? Do these practices and discourses suffice to generate a sentiment of social solidarity, loyalty, and belonging?

With the spreading of the nation-state as a monopolizing principle of sociopolitical organization, we have become unable to think of territory as decoupled from the nation (Grosby, 1995; Penrose, 2002; Yiftachel, 2002; Forsberg, 2003). Yet, in the past, this has rarely been the case. The Greek polis, for instance, which is generally regarded by political scientists as the prototype of the modern Western state, clearly kept separated the cultural community (ethnos) and the political community (demos) (Yack, 1996: 203). The link between population and territory was not based on identity, but on the political principle of a stable, ordered, peaceful, and self-sufficient democracy (Elden, 2003 - see also Vernant, 1985: 239-40; Daverio Rocchi, 1987). A similar organization of political space characterized also the Roman Republic. Roman citizenship (civitas) had first of all a political rather than a cultural content, referring in fact to the rights of cives (citizens) to actively participate to the res publica (polity) irrespective of their ethnic origin (Calhoun, 2007a; Ilari, 1980; Talamanca, 1989; Castles and Davidson, 2000; Galli, 2001). Even in the early years of the $20^{\text {th }}$ century, when the nation-state was about to emerge as the dominant principle of political organization, there were examples of polities which were not organized according to the spatial convergence of nation and state, 
like the Ottoman Empire (Isin, 2005; Birtek, 2007) and the Habsburg Empire (Unowsky, 2005; Cole and Unowsky, 2007).

I do not mention these historical examples as a way to envision a future which might look like the past, as some authors have somewhat essayed to do (e.g. Anderson, 1996; Nimni, 2005; Zielonka, 2006). Instead, the point here is to defuse a sense of historical transcendality associated with the nation-state and which obfuscates questions aimed at exploring the ways in which territory remains socially relevant even beyond the nationalist discourse of spatial convergence between nation and state. This is a point which was already raised by Soja (1971: 10) in his critique of the Western conceptualization of territory, which he saw as characterized by an ethnocentric or 'culture-bound' tendency. According to Soja (1971: 7-8), while ethnicity (or kinship) is an important mechanism in generating societal integration, this latter is also produced by two other mechanisms: the functional division of labor and the political organization of space. ${ }^{7}$ While the first mechanism has been widely investigated, particularly by neo-Marxist authors, I believe that further work is needed on the political organization of space as a mechanism of societal integration beyond an ethnocentric or 'culture-bound' perspective. The exploration of this issue becomes even more urgent today in a context in which governments struggle to search for new 'ties that bind us together' - as the 'us' has become too multiple and diverse for the concept of the ethnic or cultural nation to capture. Besides territory as a governmental strategy of control and a symbolic resource deployed by the nationalist rhetoric, scholars should investigate the ways in which territory is also discursively activated by political actors in a post-national fashion and the ways in which the simple fact of living together within the same politico-institutional bounded space generates ways of thinking, acting and being in the world which in turn contribute to the process of society-building (Delaney, 2005: 12 - see also Di Méo and Buléon, 2005: 88). As a way to illustrate further these two aspects, let me go back to the case of Britain.

Following the ethnic riots in Oldham, Burnley, and Bradford in Summer 2001 and the 7/7 London bombings, the British government has created ad hoc commissions to investigate issues of cohesion, integration, and belonging. What is common among the different reports produced by these commissions is the attempt to go beyond a notion of territory as a space of common culture or identity, stressing instead the common opportunities which can be associated with it:

"Integration and cohesion [...] is not about race, faith or other forms of group status or identity. It is simply about how we all get on and secure benefits that are mutually desirable for our communities and ourselves. It is both broad and deep, and influences all levels of activity in every part of England. As a Commission, we call for a new national campaign that promotes our shared future based on a number of key principles - those of rights and responsibilities, visible social justice, and the somewhat old fashioned sounding ethics of hospitality" (Commission on Integration \& Cohesion, 2007a: 5).

Here territory is discursively activated as a space of political, not cultural belonging, echoing the idea put forward by Bhikhu Parekh (2000) and incorporated in previous official government reports (Runnymede Trust, 2000). Any reference to common culture, values or identity is silenced and territory is only narrated as a space of common opportunities for the people who live there. 
The question to ask is whether Britain is a unique case or the discursive construction of territory as a space of political belonging based on a utilitarian rationale is an emerging trend. Moreover, to what extent does this discourse expand the notion of civic nationalism beyond its normative basis as a space of shared civic values? The stress of this new territorializing discourse, in fact, is not so much on a shared belief in democracy, equality, and other civic values, but on the expectation of 'good life', which is what generally motivates people to leave their native countries (Appadurai, 2006: 122ff). Interestingly enough, this new discursive rendition of territory seems to closely resonate with the present neo-liberal paradigm and its mechanisms of social assimilation on the basis of the individual's contribution to national economies rather than on his/her shared civic values. In this context, the studies of Mitchell (2003, 2006b) about the rhetorical emphasis of Europe's and North America's educational systems on the creation of highly mobile skilled individuals ('strategic cosmopolitans') are particularly telling of this process, which somewhat contributes to the 'de-nationalization' of territories. Yet, if this is the case, would this new post-national discourse be enough to generate social solidarity and political loyalty among the members of the same territory? Additionally, how does this discourse coexist with other discourses which, as shown above, continue to reproduce an ethnical/cultural notion of territory? And how do these opposite discourses play out in the ways people make sense of territory?

The second example which introduces the question about shared space and its implications in generating specific ways of thinking, acting and being in the world refers to the experience of a young black man, born and raised in London, who one day decides to visit for the first time Barbados, the island nation of his parents. The journey, narrated by Paul Gilroy (1993: 146ff), discloses the pleasure of the person for recovering his history and family intimacy, but also his estrangement from the place - his "being in but not really of society" (Ibid. - my italics). This episode not only reveals the condition of belonging to neither place felt by many 'second generation immigrants', but it also implicitly highlights that different places and, therefore, also different territories carry different social practices, codes, behaviors, expectations, stereotypes, etc. It is exactly these different habiti - in the Bourdieuan sense of internalized codes of behavior and thinking which affect individual and collective practices (Bourdieu, 1990: 53-55) - which life organized together within a bounded space generate; habiti, which, in turn, continuously reshape this space. To be in Britain is different from being in Barbados. However banal the phrase might sound, it exposes the importance of shared space as a factor in society-building. From this perspective, territory, as any other place, can be conceptualized as a system of social meanings produced by the continous interplay between 'top-down' discourses, policies, initiatives, etc. and 'bottom-up' prosaic practices (Mitchell, 2006: 390).

Various authors, who have essayed to rearticulate the state in the presence of ethno-cultural diversity, have often focused on the importance of individual or community rights (see, respectively, Rawls, 1993 and Kymlicka, 2001), equal access to political and economic resources (Parekh, 2000), democratic equality (Benhabib, 2002), and mutual respect, tolerance, and a sense of hospitality (Amin, 2004). Little attention, however, has been given to the basic fact of sharing the same politicoinstitutional space and its potential in generating a sense of belonging and commitment beyond the idea(1) of a common national identity. Sharing space per se elicits discourses and practices which, however conflictual and a(ntan)gonistic might be, refer and apply to a 'here' and 'now' and as such fill that space with specific social meanings (Di Méo, 1996). When India plays England at the Edgbaston cricket 
ground in Birmingham (one of the most ethnically diverse cities in Britain), the point is not to test which team British-Indians support, as controversely put forward by a British MP some years ago; but to analyze the extent to which this event creates a sentiment of commonality in the form of a shared memory for the people who live 'here' (something that other people who do not live 'here' cannot share or share to a different degree). In this sense, a shared territory is an important symbolic dimension in the production of social meanings which are generated by socio-spatial interactions, as also maintained by social psychologists (Proshansky et al. 1983). ${ }^{8}$

Obviously this 'here' can be articulated by people at different scales - spanning from the local neighborhood to Britain itself. While the local 'here' has been largely investigated with regard to processes of societal integration, the 'here' associated with the national space has been less so. Some recent reports on integration and cohesion published in Britain (Dines et al., 2006; Communities and Local Government, 2007; Commission on Integration \& Cohesion, 2007b; Buonfino and Thomson, 2007) have indeed highlighted the importance of the local scale, namely the neighborhood, as the primary unit where the encounter and the appreciation of cultural diversity can take place. Policy recommendations about breaking residential segregation have consequently been put forward. Yet, not only is there recent statistical evidence which suggests the contrary, as ethnically diverse neighborhoods are more likely to develop lack of trust, prejudice and social distances among groups than ethnically homogeneous neighborhoods (Putnam, 2007), but also these reports take for granted something which instead has to be explored, namely if and how cohesion and integration generated at a local level can transfer by default to the national scale.

Rather than being wiped away by the functioning of the new global economy, the international mobility of people, or the restructuring of the state at the sub- and supranational scale, territory remains a central dimension in the ways in which the 'living together' is produced, organized, contested and negotiated (Calhoun, 2002: 151-3; Calhoun, 2007b - see also Raffestin, 1980). In analytical terms, we should remember that this living together does not necessarily have to be based on some forms of ethnical or cultural commonality, as it can also be a sentiment of awareness of what is common (Staeheli, 2007: 5). Relying on the above discussion, I therefore suggest three ways in which this search for what is common within and in relation to territory can be operationalized. First, we should map those narratives (governmental and not) which recast territory from an ethnic, cultural, or civic space into a space of opportunities (both material and not), which guarantees a 'good life' for all its members irrespectively of their spaces of primary cultural identification. Second, we should investigate whether this discursive articulation of territory remains an abstract concept or it actually permeates the ways people talk of territory as the politicoinstitutional space within which they live. Related to this point, is the investigation of the rationale used by ethnic minorities to claim their belonging 'here', i.e. to a given politico-institutional space. On what basis is this claim put forward: citizenship, shared values, historical or cultural ties, material contribution to the hosting society? Third, these top-down and bottom-up discourses need to be analyzed in terms of both state and people practices, as a way to explore further the institutionalization of territory as a national and/or post-national space. These three avenues of research do not pretend to be exhaustive; rather they are just a starting point to investigate the significance of territory within and beyond the spatial isomorphism embodied by the idea of nation-state. 


\section{Where shall we go from here? Conclusions and conjectures}

In the context of the crisis of the hyphen, the temptation to discard territory as the device which has permitted the discursive convergence between nation and state has surfaced in various post-national, cosmopolitan, and post-sovereignty discourses. Since the 1980s, critical geographers have also increasingly turned their attention away from bounded spaces, in favor of open, relational places as a way to better grasp a reality shaped by flows, networks, and the interplay of scales. In the present article, I have argued for the need to explore further, rather than downplay the role of territory in the age of globalization and multiculturalism. My argument is that rather than wishing territory away in the midst of processes of state restructuring it would be more meaningful to explore in which ways territory as a politico-institutional bounded space remains an important factor in society-building. Until now, territory has been treated either as a device in the hands of the state to control, contain, and discipline people or as a symbolic source of national identification. I believe that, although correct, these ways of looking at territory entail unwanted consequences. In the first case, in fact, this view treats people just as passive subjects, waiting to be contained, controlled, disciplined or simply disposed by an all-pervasive state power - a view which seems to characterize also the recent reflections on our present condition as homini sacri (Agamben, 1988; Minca, 2006, 2007). In the second case, the interpretation remains unable to analytically differentiate between territory as a space of socio-political organization and territory as a source of ethno-cultural identity - a historically contingent spatial coincidence which the nation-state has discursively propagated, but which today, in Western Europe as well as in other parts of the world, the changing ethnic composition of national societies, among other factors, renders more problematic.

Looking at the measures adopted by some Western European countries to tackle what I have called the 'crisis of the hyphen', a contradictory reaction is noticeable. On the one hand, in fact, some governments have started a process of 'deethnicization' of the nation, replacing its ethno-cultural heritage with generic principles of tolerance, respect, democracy, etc. ${ }^{9}$ On the other hand, the same governments have recently adopted measures which indirectly try to preserve the ethno-cultural identity of territory, by either limiting new immigration and/or testing the cultural compatibility of the new immigrants. While the latter strategy clearly resonates with the idea of territory as a principle of national identity, the former stance opens up space for what can be labeled a 'post-national notion of territory'. Within this perspective, territory emerges as a sort of 'space of political belonging', which is not necessarily defined in terms of some common cultural values and within, across, and beyond which multiple 'spaces of cultural identification' can exist. ${ }^{10}$ While the 'space of political belonging' is geographically contiguous and enclosed by territorial boundaries, 'spaces of cultural identification' are less so, as they can span over multiple scales and their boundaries are social rather than geographical. In this sense, it is as if the politico-institutional and the cultural operate at different levels, echoing the theoretical distinction put forward by Habermas.

This is just one possible way to reconceptualize the notion of territory in a postnational fashion. Empirical evidence emerging from interviews with immigrants in America and Europe (Kastoryano, 2002; Nagel and Staeheli, 2005; Brettell, 2006; 
Leitner and Ehrkamp, 2006) suggests that this conceptualization finds more ground than what might appears at first sight. These studies have indeed clearly shown that even if immigrants feel emotionally attached to their spaces of origin, they equally feel a sense of loyalty to the politico-institutional space which guarantees them and their children a condition of material security (Appadurai, 2006 - see also Waller and Linklater, 2003). In other words, for these respondents the space of their cultural identification does not necessarily coincide with the space of their political belonging.

In the rush to theorize new post-national scenarios, many authors have fallen into the trap of confusing post-national with post-territorial. This has obviously limited their analytical insight, since, if Berezin (2003: 2) is right, territory is an inescapable principle of social life. A recent attempt to bring territory back into the analysis of networks, places, and scales has been advanced by Jessop et al. (2008). Their call for a simultaneous analysis of all these different socio-spatial categories is theoretically well argued. Yet, it consciously remains indifferent to the reconceptualization of each of these categories. Thus, in their analysis, territory is treated in a rather conventional way, as the space organized by the modern nation-state. The present article has shown that while this remains a legitimate and enduring principle, it has been flanked by alternative ways of conceiving and living in territory, beyond the socio-spatial congruence of nation and state.

In the age of globalization, the most likely scenario is neither a watering down of all identities within a given territory (Haesbaert, 2001), nor the de-territorialization of collective identities (Scholte, 1996), rather the persistence of thick cultural identities imbricated with territory in multiple relations. Thus, rather than simply dismissing the re-nationalization of territories in the age of globalization as 'systemically unsustainable' (Sassen 2006: 414), it seems more appropriate to investigate how, when, where, and by whom territory is produced, narrated and practiced in forms which at times resonate with a national perspective and at times with a post-national one (and how these two different ways of organizing social space coexist). In an epoch of flows, networks, overlapping scales, multiculturalism, and hybridity, it is more than ever necessary to explore what remains bounded.

\section{References}

Agamben, G. 1988: Homo Sacer: Sovereign Power and Bare Life Stanford: Stanford University Press. Agnew, J. 1994: The territorial trap: The geographical assumptions of international relations theory. Review of International Political Economy 1, 53-80.

Agnew, J. 1999: Mapping political power beyond state boundaries: Territory, identity, and movement in world politics. Millennium-Journal of International Studies 28, 499-521.

Agnew, J. A. 2002: Place and Politics in Modern Italy. Chicago: University of Chicago Press.

Alliès, P. 1980: L'Invention du territoire. Grenoble: Presses Universitaires de Grenoble.

Amin, A. 2002a: Spatialities of Globalisation. Environment and Planning A 34, 385-399.

Amin, A. 2002b: Ethnicity and the multicultural city: living with diversity. Environment and Planning A 34, 959-980.

Amin, A. 2004: Multi-ethnicity and the idea of Europe. Theory, Culture \& Society 21, 1-24.

Anderson, J. 1996: The shifting stage of politics: New medieval and postmodern territorialities? Environment and Planning D: Society and Space 14, 133-153.

Appadurai, A. 1990: Disjuncture and difference in the global cultural economy. Public Culture 2, 1-24.

Appadurai, A. 1996: Sovereignty without Territoriality: Notes for a Postnational Geography. In Yaeger, P., editor, The Geography of Identity, Ann Arbor: The University of Michigan Press, 40-58. 
Appadurai, A. 2006: Fear of small numbers. An essay on the geography of anger. Durham: Duke University Press.

Ardrey, R. 1967: The Territorial Imperative: A Personal Inquiry into the Animal Origins of Property and Nations London: Collins.

Badie, B. 1995: La fin des territoires. Essai sur le désordre international et sur l'utilité sociale du respect. Paris: Fayard.

Barnett, C. 2004: Deconstructing radical democracy: Articulation, representation, and being-withothers. Political Geography 23, 503-528.

Bassin, M. 1987: Imperialism and the nation state in Friedrich Ratzel's political geography. Progress in Human Geography 11, 473-495.

Beauchard, J. 2001: Penser l'unité politique entre fondements, turbulences, et mondialisation. Paris: l'Harmattan.

Beauchard, J. 2003: Génie du territoire et identité politique. Paris: l'Harmattan.

Bendersky, J. W. 1983: Carl Schmitt. Theorist for the Reich. Princeton: Princeton University Press.

Benhabib, S. 2002: The claims of culture. Equality and diversity in the global era. Princeton, NJ: Princeton University Press.

Berezin, M. 2003: Introduction: Territory, Emotion, and Identity: Spatial Recalibration in a New Europe. In Berezin, M. and Schain, M., editors, Europe without Borders : Remapping Territory, Citizenship, and Identity in a Transnational Age, Baltimore: Johns Hopkins University Press, 1-30.

Bobbitt, P. 2003: The shield of Achilles. War, peace, and the course of history. New York: Anchor Books.

Bourdieu, P. 1990: The Logic of Practice. Cambridge: Polity Press.

Birtek, F. 2007: From affiliation to affinity: Citizenship in the transition from empire to the nationstate. In Benhabib, S., Shapiro, I. and Petranović, D., editors, Identities, affiliations, and allegiances, Cambridge: Cambridge University Press, 17-44.

Braun 2001: Producing vertical territory: Geology and governmentality in late Victorian Canada. Ecumene 7, 7-46.

Brenner, N. 1999: Globalisation as Reterritorialisation: The Re-scaling of Urban Governance in the European Union. Urban Studies 36, 431-451(21).

Brenner, N., Jessop, B., Jones, M.and Macleod, G., editors 2003: State/Space: A Reader. Malden, MA: Blackwell.

Brettell, C. B. 2006: Political belonging and cultural belonging. Immigration status, citizenship, and identity among four immigrant populations in a Soutwestern city. American Behavioral Scientist 50, 70-99.

Brown, G. 2004: Annual British Council Lecture. The Guardian, 8 July.

Brown, G. 2007: We need a United Kingdom. The Telegraph, 13 January.

Buonfino, A.and Thomson, L. 2007: Belonging in contemporary Britain. London, Commission on Integration and Cohesion.

Calhoun, C., editor 1992a: Habermas and the Public Sphere, Cambridge, Mass.: The MIT Press.

Calhoun, C. 1992b: Introduction: Habermas and the Public Sphere. In Calhoun, C., editor, Habermas and the Public Sphere, Cambridge, Mass., 1-48.

Calhoun, C. 2002: Imagining solidarity: Cosmopolitanism, constitutional patriotism, and the public sphere. Public Culture 14, 147-171.

Calhoun, C. 2007a: Nations matter: citizenship, solidarity and the cosmopolitan dream London: Routledge.

Calhoun, C. 2007b: Social solidarity and cosmopolitan democracy. In Benhabib, S., Shapiro, I. and Petranović, D., editors, Identities, Affiliations, and Allegiances, Cambridge: Cambridge University Press, 285-302.

Castles, S.and Davidson, A. 2000: Citizenship and Migration. Globalization and the Politics of Belonging. New York: Routledge.

Castree, N. 2004: Differential geographies: place, indigenous rights and 'local' resources. Political Geography 23, 133-167.

Cederman, L.-E. 2001: Nationalism and Bounded Integration: What it Would Take to Construct a European Demos. European Journal of International Relations 7, 139-174.

Cesari, J. 2005: Ethnicity, Islam, and les banlieues: Confusing the Issues. New York, SSRC.

Cole, L.and Unowsky, D. L., editors 2007: The Limits of Loyalty. Imperial Symbolism, Popular Allegiances, and State Patriotism in the Late Habsburg Monarchy. New York: Berghahn Books. 
Commission on Integration \& Cohesion, 2007a: Our shared future. London: Commission on Integration \& Cohesion (www.integrationandcohesion.org.uk)

Commission on Integration \& Cohesion, 2007b: Bringing communities and people together. London: Commission on Integration \& Cohesion (www.integrationandcohesion.org.uk)

Communities and Local Government, 2007: 'What works' in community cohesion. London: Department for Communities and Local Government (www. communities.gov.uk)

Corbett, D. 2006: Testing the Limits of Tolerance. Deutsche Welle.29 October

Cox, K. R., editor 1997: Spaces of Globalization: Reasserting the Power of the Local, New York: Guilford.

Cox, K. R. 2002: Political Geography. Territory, State and Society. Oxford: Blackwell.

Daverio Rocchi, G. 1987: Il concetto di frontiera nella Grecia antica. In Sordi, M., editor, Il confine nel mondo classico, Milano: Vita e Pensiero, 21-42.

Delaney, D. 2005: Territory. A short Introduction. Oxford: Blackwell.

Deleuze, G.and Guattari, F. 1987: Capitalism and Schizophrenia. A Thousand Plateaus (vol. II). Minneapolis: Minnesota University Press.

Di Méo, G., editor 1996: Les territoires du quotidien, Paris: l'Harmattan.

Di Méo, G.and Buléon, P. 2005: L'espace sociale. Lecture géographique des sociétés. Paris: Armand Colin.

Dines, N., Cattell, V., Gesler, W.and Curtis, S. 2006: Public spaces, social relations and well-being in East London. London: Joseph Rowntree Foundation.

Elden, S. 2003: Another sense of 'demos': Kleisthenes and the Greek division of the 'polis'. Democratization 10, 135-156.

Elden, S. 2007: Governmentality, calculation, territory. Environment and Planning D: Society and Space 25, 562-580.

Escobar, A. 2001: Culture sits in places: reflections on globalism and subaltern strategies of localization. Political Geography 20, 139-174.

Etzioni, A. 2007: Citizenship tests: A comparative, communitarian perspective. The Political Quarterly 78, 353-363.

Featherstone, D. 2007: Contesting the political. Area 39, 131-132.

Forsberg, T. 1996: Beyond sovereignty, within territoriality. Mapping the space of late-modern (geo)politics. Cooperation and Conflict 31, 355-386.

Forsberg, T. 2003: The ground without foundation? Territory as a social construct. Geopolitics 8, 7-24.

Foulkes, I. (2007) Swiss row over black sheep poster. BBC News.

Fraser, N. 2007: Transnationalizing the public sphere: on the legitimacy and efficacy of public opinion in a postWestphalian world. In Benhabib, S., Shapiro, I. and Petranović, D., editors, Identities, affiliations, and allegiances, Cambridge: Cambridge University Press, 45-66.

Friedman, T. 2005: The World is Flat: A Brief History of the Twenty-first Century. New York: Farra, Straus and Giroux.

Fukuyama, F. 1989: The end of history? The National Interest 16, 3-18.

Galli, C. 2001: Spazi politici. L'età moderna e l'età globale. Bologna: Il Mulino.

Gottman, J. 1973: The Significance of Territory. Charlottesville: University of Virginia Press.

Gottman, J. 1975: The evolution of the concept of territory. Social Science Information 14, 29-47.

Graham, S. 1998: The end of geography or the explosion of place? Conceptualizing space, place and information technology. Progress in Human Geography 22, 165-185(21).

Grosby, S. 1995: Territoriality: The transcendental, primordial feature of modern societies. Nations and Nationalism 1, 143-162(20).

Guéhenno, J.-M. 1995: The End of the Nation-State. Minneapolis: University of Minnesota Press.

Habermas, J. 1989: The Structural Transformation of the Public Sphere. Cambridge, Mass.: The MIT Press.

Habermas, J. 1992: Citizenship and national identity: Some reflections on the future of Europe. Praxis International 12, 1-19.

Habermas, J. 1998: The Inclusion of the Other. Studies in Political Theory. Cambridge, Mass: MIT.

Habermas, J. 2001: The Postnational Constellation: Political essays. Cambridge, Mass: MIT.

Haesbaert, R. 2001: Le mythe de la déterritorialisation. Géographie et cultures 40, 53-75.

Häkli, J. 2001: In the territory of knowledge: state-centred discourses and the construction of society. Progress in Human Geography 25, 403-422(20).

Hannah, M. G. 2000: Governmentality and the Mastery of Territory in Nineteenth-Century America. Cambridge: Cambridge University Press.

Herb, G. H. 2004: Double Vision: Territorial Strategies in the Construction of National Identities in Germany, 1949-1979. Annals of the Association of American Geographers 94, 140-164(25). 
Herod, A. and Wright, M. W., editors 2002: Geographies of Power. Placing Scale, Oxford: Blackwell. Home Office 2001: Community Cohesion (The Cantle Report). London: The Stationery Office.

Howitt, R. 2003: Scale. In Agnew, J., Mitchell, K. and Toal, G., editors, A Companion to Political Geography, Oxford: Blackwell, 138-157.

Ilari, V. 1980: Guerra e diritto nel mondo antico. Milano: Giuffré.

Isin, E. F. 2005: Citizenship after orientalism. Ottoman citizenship. In Keyman, F. and Içduygu, A., editors, Citizenship in a global world: European questions and Turkish experiences, London: Routledge.

Jessop, B. 2000: The Crisis of the National Spatio-Temporal Fix and the Tendential Ecological Dominance of Globalizing Capitalism. International Journal of Urban and Regional Research 24, 323-360.

Jessop, B., Brenner, N. and Jones, M. 2008: Theorizing sociospatial relations. Environment and Planning D: Society and Space 26, 389-401.

Judt, T.and Lacorne, D. 2004: Language, nation and state: identity politics in a multilingual age. New York: Basingstoke

Kastoryano, R. 2002: Citizenship and Belonging: Beyond Blood and Soil. In Hedetoft, U. and Hjort, M., editors, The Postnational Self. Belonging and Identity, Minneapolis: University of Minnesota Press, 120-136.

Keith, M.and Pile, S., editors 1993: Place and the Politics of Identity, London: Routledge.

Knight, D. B. 1999: Bounding whose territory? Potential conflict between a state and a province desiring statehood. Geopolitics 4, 209-.

Kohli, M. 2000: The battlegrounds of European identity. European Societies 2, 113-137.

Kymlicka, W. 2001: Politics in the Vernacular: Nationalism, Multiculturalism, and Citizenship New York: Oxford University Press.

La Tribune, 2007: Nicolas Sarkozy en appelle à "tous les Français de bonne volonté". LaTribune.fr, 22 April.

Lee, S. 2006: Gordon Brown and the 'British Way'. The Political Quarterly 77, 369-378.

Leitner, H.and Ehrkamp, P. 2006: Transnationalism and migrants' imaginings of citizenship. Environment and Planning A 38, 1615-1632.

Lévy, J. 2007: Globalization as a political invention: Geographical lenses. Political Geography 26, 1319.

Maier, C. M. 2007: Place, Territory, and Identity. In Benhabib, S., Shapiro, I. and Petranović, D., editors, Identities, Affiliations, and Allegiances, Cambridge: Cambridge University Press, 8467.

Mason, A. 1999: Political community, liberal-nationalism, and the ethics of assimilation. Ethics 109, 261-286.

Massey, D.and Jess, P., editors 1995: A Place in the World? Places, Cultures and Globalization, Oxford: Oxford University Press.

Miller, D. 2000: Citizenship and National Identity. Cambridge: Polity Press.

Minca, C. 2006: Giorgio Agamben and the new biopolitical Nomos. Geografiska Annaler B 88, 387 403.

Minca, C. 2007: Agamben's geographies of modernity. Political Geography 26, 78-97.

Mitchell, K. 2003: Educating the national citizen in neoliberal times: from the multicultural self to the strategic cosmopolitan. Transactions of the Institute of British Geographers 28, 387-403.

Mitchell, K. 2006a: Geographies of identity: the new exceptionalism. Progress in Human Geography 30, 95-106.

Mitchell, K. 2006b: Neoliberal governmentality in the European Union: education, training, and technologies of citizenship. Environment and Planning D: Society and Space 24, 389-407.

Mouffe, C. 1999: Carl Schmitt and the Paradox of Liberal Democracy. In Mouffe, Chantal, editor, The Challenge of Carl Schmitt, London: Verso, 38-53.

Mouffe, C., editor 1999b: The Challenge of Carl Schmitt, London: Verso.

Mouffe, C. 2005: On the Political. London: Routledge.

Murphy, A. B. 2002: National Claims to Territory in the Modern State System: Geographical Considerations. Geopolitics 7, 193-214(22).

Nagel, C. R.and Staeheli, L. 2005: "We're just like the Irish": Narratives of assimilation, belonging and citizenship amongst Arab-American activists. Citizenship Studies 9, 485-498.

Newman, D. 2003: Boundaries. In Agnew, J., Mitchell, K. and Ó Tuathail, G., editors, A Companion to Political Geography, Oxford: Blackwell, 123-137.

Newman, D. 2006: The lines that continue to separate us: Borders in our 'borderless' world. Progress in Human Geography 30, 143-161. 
Nimni, E. 1999: Nationalist multiculturalism in late imperial Austria as a critique of contemporary liberalism: the case of Bauer and Renner. Journal of Political Ideologies 4, 289-314.

Nimni, E., editor 2005: National cultural autonomy and its comtemporary critics, London: Routledge. O' Brien, R. 1992: Global Financial Integration: The End of Geography. London: Pinter.

O' Loughlin, J.and Ó Tuathail, G. forthcoming: Accounting for separatist sentiment in BosniaHerzegovina and the North Caucasus of Russia: A comparative analysis of survey responses. Ethnic and Racial Studies.

Ó Tuathail, G. 1996: Critical Geopolitics. Minneapolis: Minnesota University Press.

Ó Tuathail, G.and Luke, T. W. 1994: Present at the (dis)integration: Deterritorialization and reterritorialization in the new wor(l)d order. Annals of the Association of American Geographers 84, 381-398.

Oakes, T. 1997: Place and the Paradox of Modernity. Annals of the Association of American Geographers 87, 509-531.

OECD 2007: International Migration Outlook. Annual Report 2007. Paris: OECD.

Ohmae, K. 1995: The end of the nation state. The rise of the regional economies. London: The Free Press.

Paasi, A. 2003: Territory. In Agnew, J., Mitchell, K. and Ó Tuathail, G., editors, A Companion to Political Geography, Oxford: Blackwell, 109-122.

Painter, J. 2006: Territory - Network. Paper presented at the Annual meeting of the AAG, Chicago, 711 March.

Parekh, B. 2000: Rethinking multiculturalism. Cultural diversity and political theory. London: Macmillan Press.

Penrose, J. 2002: Nations, states and homelands: territory and territoriality in nationalist thought. Nations and Nationalism 8, 277-297.

Pratt, G. 1999: Geographies of Identity and Difference: Marking Boundaries. In Massey, D., Allen, J. and Sarre, P., editors, Human Geography Today, Cambridge: Polity Press, 151-167.

Pugh, J., Hewett, C.and Chandler, D. 2007: Debating (de)territorial governance. Area 39, 107-119.

Putnam, R. D. 2007: E Pluribus Unum: Diversity and community in the twenty-first century. Scandinavian Political Studies 30, 137-174.

Raffestin, C. 1980: Pour une géographie du pouvoir. Paris: LITEC.

Ratzel, F. 1923: Politische Geographie. München: Oldenbourg.

Rawls, J. 1993: Political liberalism. New York: Columbia University Press.

Population and Development Review, 2006: On Integrating Immigrants in Germany. Population and Development Review 32, 597-600.

Proshansky, H. M., Fabian, A. K.and Kaminoff, R. 1983: Place-identity: Physical world socialization of the self. Journal of Environmental Psychology 3, 57-83.

Rose, G. 1995: Place and Identity: A Sense of Place. In Massey, D. and Jess, P., editors, A Place in the World, Oxford: Open University Press, 87-132.

Rose, N. 1996: The death of the social? Re-figuring the territory of government. Economy and Society 25, 327-356.

Roy, O. 2005: The nature of the French riots. New York, SSRC.

Ruggie, J. G. 1993: Territoriality and Beyond: Problematizing Modernity in International Relations. International Organization 47, 139-174.

Runnymede Trust, 2000: The future of multi-ethnic Britain (The Parekh report). London: Profile Books.

Sack, R. 1986: Human Territoriality. Its Theory and History. Cambridge: Cambridge University Press.

Sassen, S. 1996: Losing Control? Sovereignty in an Age of Globalization. New York: Columbia University Press.

Sassen, S. 2006: Territory, Authority, Rights. From Medieval to Global Assemblages. Princeton: Princeton University Press.

Scholte, J. A. 1996: The geography of collective identities in a globalizing world. Review of International Political Economy 3, 565-607.

Scott, A. J.and Storper, M. 2003: Regions, Globalization, Development. Regional Studies 37, 579-593.

Soja, E. W. (1971) The Political Organization of Space. Washington, DC, Association of American Geographers.

Sparke, M. 2006: Political geography: political geographies of globalization (2) - governance.

Progress in Human Geography 30, 357-372.

Staeheli, L. 2007: Citizenship and the problem of community. Political Geography forthcoming.

Storey, D. 2001: Territory: The Claiming of Space. Harlow: Prentice Hall.

Talamanca, M., editor 1989: Lineamenti di storia del diritto romano, Milano: Giuffré. 
Taylor, P. J. 1994: The state as container: territoriality in the modern world-system. Progress in Human Geography 18, 151-162.

Taylor, P. J. 1995: Beyond containers: internationality, interstateness, interterritoriality. Progress in Human Geography 19, 1-15.

Taylor, P. J. 1996: Embedded statism and the social sciences: Opening up to new spaces. Environment and Planning A 28, 1917-1928.

Taylor, P. J. 2000: World cities and territorial states under conditions of contemporary globalization. Political Geography 19, 5-32.

Taylor, R. B. 1988: Human Territorial Functioning. An Empirical, Evolutionary Perspective on Individual and Small Group Territorial Cognitions, Behaviors, and Consequences Cambridge: Cambridge University Press.

Teschke, B. 2002: Theorizing the Westphalian System of States: International Relations from Absolutism to Capitalism. European Journal of International Relations 8, 5-48(44).

Tully, J. 1995: Strange Multiplicities: Constitutionalism in an Age of Diversity. Cambridge: Cambridge University Press.

United Nations, 2000: Replacement migration: Is it a solution to declining and aging population? New York: United Nations Press (Population Division, Department of Economic and Social Affairs).

Unowsky, D. 2005: The Pomp and Politics of Patriotism. Imperial Celebrations in Habsburg Austria, 1848-1916. West Lafayette, Indiana: Purdue University Press.

Valentino, P. 2006: Test di morale per aspiranti tedeschi. Corriere della Sera. 5 January.

Vasudevan, A., Mcfarlane, C. and Jeffrey, A. 2008: Spaces of enclosure. Geoforum 39, 1641-1646.

Vernant, J.-P. 1985: Mythe et pensée chez les Grecs. Etudes de psycologie historique. Paris: Editions la Découverte.

Wæver, O. 1995: Identity, integration and security. Solving the sovereignty puzzle in E.U. studies. Journal of International Affairs 48, 389-431.

Walker, R. B. J. 1993: Inside/Outside: International Relations as Political Theory. Cambridge: Cambridge University Press.

Waller, M.and Linklater, A., editors 2003: Political Loyalty and the Nation-State, London: Routledge.

Williams, J. 2003: Territorial borders, international ethics and geography: Do good fences still make good neighbours? Geopolitics 8, 25-46.

Yack, B. 1996: The myth of the civic nation. Critical Review 10, 193-211.

Yeung, H. W.-C. 1998: Capital, state and space: Contesting the borderless world. Transactions of the Institute of British Geographers NS 23, 291-309.

Yiftachel, O. 2002: Territory as the kernel of the nation: Space, time and nationalism in Israel/Palestine. Geopolitics 7, 215-248.

Zielonka, J. 2006: Europe as Empire. The nature of the enlarged European Union. Oxford: Oxford University Press.

\footnotetext{
${ }^{1}$ Recent attempts which have carried out a similar research are those of Beauchard (2001, 2003), Painter (2006), and Pugh et al. (2007).

2 According to the OECD, the notion of 'foreign-born' "can be viewed as representing first-generation migrants and may consist of both foreign and national citizens" (OECD, 2007: 60). In order not to affect the mean value, data for Switzerland (23.8\%) and for Luxembourg (33.4\%) - this latter being a country with a high presence of foreign personnel working for the EU - have not been counted. All data refer to the year 2005, except data for Germany (year 2003) and for Italy, Spain and Greece (year 2001). Data are available online at http://dx.doi.org/10.1787/015587767146.

${ }^{3}$ As observed by one anonymous reviewer, particularly after $9 / 11$ these measures can also certainly be interpreted as a way "to secure the institutional state structures by transforming the images of threats in foreign policy". This discursive process, which ends up securitizing migration issues (see, for instance, the debate in the US about the construction of the fence with Mexico), is certainly at play within Western societies, but I would argue that it does not contradict the fact that anti-migration measures, in practice, reinforce an ethno-cultural view of the nation.
} 
${ }^{4}$ The National Integration Plan, adopted in 2007, is the concerted effort of the federal government, federal Länder, local authorities, associations of migrants and other NGOs. For further information see www.Nationaler-Integrationsplan.de

${ }^{5}$ See the interview with Abdullah Gül in the Süddeutsche Zeitung (2 April 2007). For a summary of the protests of the Turkish associations and of the commentaries of major Germany's newspapers see the article of David Gordon Smith in Spiegel International ("Immigration Law 'Hits Turks Below the Belt"'), July 12, 2007. Available online at

http://www.spiegel.de/international/germany/0,1518,494027,00.html.

${ }^{6}$ Another interesting attempt to go beyond the isomorphism between nation and state is the model of 'national cultural autonomy' introduced by the Austrian socialist politicians Bauer and Renner in the late $19^{\text {th }}$ century. This model, which granted non-territorial autonomy to national communities while keeping the administrative unity of the multinational state, has recently been put forward again as a way to overcome the limits associated with liberalist and communitarian solutions to the problem of recognition in multicultural societies (Nimni, 1999, 2005).

${ }^{7}$ It is interesting to observe that also the 'father of political geography', Friedrich Ratzel, in his definition of Volk (people), emphasized the role of territory as a principle of social integration: "[Volk is] a politically united body made up of groups and individuals, who need neither to be related ethnically nor linguistically, but who through their common territory are spatially linked together (verbundene)" (Ratzel, 1923 quoted in Bassin, 1987, p. 480).

${ }^{8}$ Environmental psychologists, in particular those who espouse a symbolic interactionist paradigm, have largely investigated this issue. See the various articles published in the Journal of Environmental Psychology.

${ }^{9}$ In this regard, it is significant, for instance, that citizenship, as it is granted through the naturalization process, only demands - at least on paper - respect of rights, fulfillment of duties and loyalty to the country. This is what the British government, among others, requires its new citizens to pledge. See

http://www.ind.homeoffice.gov.uk/applying/nationality/citizenshipceremonies/

A similar oath is in force also in the United States - see http://www.uscis.gov/portal/site/uscis.

${ }^{10}$ For example, Welsh living in Britain (i.e. within a given politico-institutional territory); Istrians living in Italy, Slovenia, and Croatia (whose cultural identity is articulated across different territories); religious communities (e.g. Muslim) or national diasporas spread all over the world, i.e. beyond any given territory. The conceptual distinction between a space of political loyalty and a space of cultural belonging has been put forward also by Wæver (1995) in relation to Europe. 